\title{
Stability Study of Flat Hull Ship for Fishing Tourism
}

\author{
Rahmat Azis Nabawi, Syahril and Salmat \\ Jurusan Teknik Mesin, Fakultas Teknik, Universitas Negeri Padang, Indonesia
}

\begin{tabular}{|c|c|}
\hline Article Info & ABSTRACT \\
\hline Article history: & The availability of boats is needed to develop fishing tourism. Most of the \\
\hline Received Jun $22^{\text {th }}, 2020$ & $\begin{array}{l}\text { boats used so far generally use fishing boats made of woodcut in the forest, } \\
\text { so this can damage the environment and cause natural disasters. Ships using }\end{array}$ \\
\hline Revised Aug $15^{\text {th }}, 2020$ & a flat plate hull made of steel can be a substitute for wooden ships. This study \\
\hline Accepted Nov $29^{\text {th }}, 2020$ & $\begin{array}{l}\text { aims to test the stability of a flat plate vessel designed for fishing boats. The } \\
\text { ship stability test was carried out using a computer simulation method using }\end{array}$ \\
\hline Keywords: & $\begin{array}{l}\text { Maxsurf Stability software. The ship stability criteria refer to the } \\
\text { International Maritime Organization code A.749 (18), Ch 3-design criteria }\end{array}$ \\
\hline Fishing tourism & applicable to all ships. The ship stability analysis was carried out on two \\
\hline Flat hull ship & variations of the load case. The value of $G Z$ at $A h 30^{\circ}, A h 40^{\circ}$ and $A h 30^{\circ}-$ \\
\hline Ship stability & A $h 40^{\circ}$ for load case 1 and 2 are greater than the minimum standards \\
\hline IMO & $\begin{array}{l}\text { determined by IMO. The maximum GZ value at load case } 1 \text { occurs at an } \\
\text { angle of } 40^{\circ} \text { and at load case } 2 \text { at an angle of } 60.9^{\circ} \text {. The GM value in load } \\
\text { case } 1 \text { is } 0.609 \text { meters and in load case } 2 \text { is } 0.485 \text { meters. Based on the } \\
\text { results of the tests that have been carried out, it can be denied that the } \\
\text { flatboat design model for fishing tourism meets the criteria set by the } \\
\text { International Maritime Organization. }\end{array}$ \\
\hline
\end{tabular}

Corresponding Author:

Rahmat Azis Nabawi,

Jurusan Teknik Mesin, Fakultas Teknik, Universitas Negeri Padang

Jln. Prof. Dr. Hamka Air Tawar, Padang (25131), Sumatera Barat, Indonesia

Email: raazna@ft.unp.ac.id

\section{INTRODUCTION}

Indonesia has great potential for this fishing tourism activity. Fishing tourism activities are very much in demand from both local and international tourists. The development of marine ecotourism will have a big impact on the welfare of the community [1]. To support and develop this fishing tourism, the main facilities are needed, namely boats. Ships commonly used for fishing tourism activities are fishing boats made of wood. The use of wood as a material for shipbuilding is not environmentally friendly and the use of aluminium as a material for shipbuilding requires high costs [2]. The need for innovation to solve this problem.

Ships with the flat plate hull method can be an alternative technology for producing ships because it is easy in the manufacturing process and does not require high technology so that shipbuilding costs are not too expensive [3][4]. Flat hull ship is a technology that uses steel can be a solution as an alternative to wooden boats and fibreglass boats [5]. Indonesia as an archipelago can use flat hull ship [6].

The application of the flat hull ship method on this fishing tour boat can be a solution in anticipating that there is no longer logging in the forest as a material for ships. The simplicity and low cost of production ships using flat hull ship can be an innovation in the design and manufacture of ships community shipbuilding businesses. The availability of fishing tourism boats will also increase the interest of tourists to visit Indonesia. This article discusses a flat hull ship stability study for tourist fishing boats. Stability testing is an important factor to study because it is closely related to the safety of the ship while sailing.

\section{METHOD}

Ship stability testing is carried out using numerical methods using Maxsurf Software. Stages of the ship stability study began by making a flat hull ship for fishing tourism boat model used the Maxsurf Modeller, ship stability test using Maxsurf Stability and checking the conformity of the test results with the ship stability criteria listed in the International Maritime Organization code A.749 (18), Ch 3-design criteria for applicable to all ships [7]. The stages of research implementation are shown in Fig. 1. 


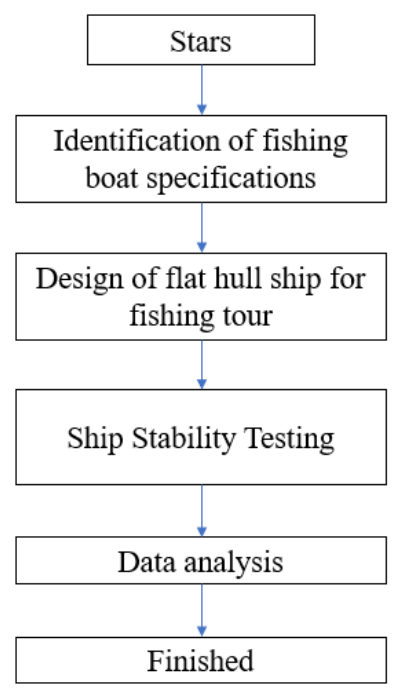

Figure $1:$ Stages of research implementation

Ship stability analysis using Maxsurf Stability Software on two load case variations as follows:

1. The ship is in a condition with the equipment installed and without passengers.

2. The ship is in a condition with the equipment that has been installed and has six passengers (maximum passenger condition).

The fixed payload of the ship is deadweight Tonnage, propulsion engine, transmission system, shaft and propeller, navigation equipment, safety equipment, fuel tank, the water tank and logistics. More complete data on ship cargo conditions are presented in table 1.

Table 1 : Load case conditions

\begin{tabular}{|c|c|c|}
\hline Load Case & K1 & K2 \\
\hline Deadweight Tonnage & $650 \mathrm{Kg}$ & $650 \mathrm{Kg}$ \\
\hline Machine & $70 \mathrm{Kg}$ & $70 \mathrm{Kg}$ \\
\hline Transmission system & $50 \mathrm{Kg}$ & $50 \mathrm{Kg}$ \\
\hline Shaft and propeller & $50 \mathrm{Kg}$ & $50 \mathrm{Kg}$ \\
\hline Navigation equipment & $20 \mathrm{Kg}$ & $20 \mathrm{Kg}$ \\
\hline Safety equipment & $100 \mathrm{Kg}$ & $100 \mathrm{Kg}$ \\
\hline Fuel tank & $100 \mathrm{Kg}$ & $100 \mathrm{Kg}$ \\
\hline Water tank & $100 \mathrm{Kg}$ & $100 \mathrm{Kg}$ \\
\hline Logistics & $100 \mathrm{Kg}$ & $100 \mathrm{Kg}$ \\
\hline Crew (2 persons, @ $\pm 70 \mathrm{Kg}$ ) & $140 \mathrm{Kg}$ & $140 \mathrm{Kg}$ \\
\hline Passenger (6 persons, $@ \pm 70 \mathrm{Kg}$ ) & - & $420 \mathrm{Kg}$ \\
\hline Total & $1380 \mathrm{Kg}$ & $1800 \mathrm{Kg}$ \\
\hline
\end{tabular}

The ship stability criteria based on the International Maritime Organization code A.749 (18), Ch 3design criteria applicable to all ships [7] are as follows:

a. The area under righting lever curve (GZ curve) shall not be less than 0.055 -metre radians up to 30 degrees heeling angle

b. The area under the righting lever curve (GZ curve) shall not be less than 0.090-metre radians up to 40 degrees heeling angle or the angle of down-flooding if this is less than 40 degrees 
c. The area under the righting lever arm curve (GZ curve) between the heeling angles of 30 degrees and 40 degrees or between 30 degrees and the angle of down-flooding, if this is less than 40 degrees, shall not be less than 0.03 meter-radians

d. The righting lever GZ shall be at least $0.2 \mathrm{~m}$ at a heeling angle equal to or greater than $30^{\circ}$

e. The maximum righting lever shall occur at an angle of heel not less than $25^{\circ}$

f. The initial metacentric height GM0 shall not be less than $0.15 \mathrm{~m}$

The dimensions of the ship are designed with reference to the commonly used fishing boats for fishing tourism boats (Table 2). The design of a fishing tourism boat using a flat plate hull is shown in Figure 2.

Table 2 : Specifications of fishing tourism boats

\begin{tabular}{lc}
\hline \multicolumn{1}{c}{ Specification } & Dimension (metre) \\
\hline Length of All & 10 \\
Length Water Line & 9.3 \\
Beam & 1.6 \\
Breadth at The Waterline & 1.5 \\
Depth & 1 \\
\hline
\end{tabular}
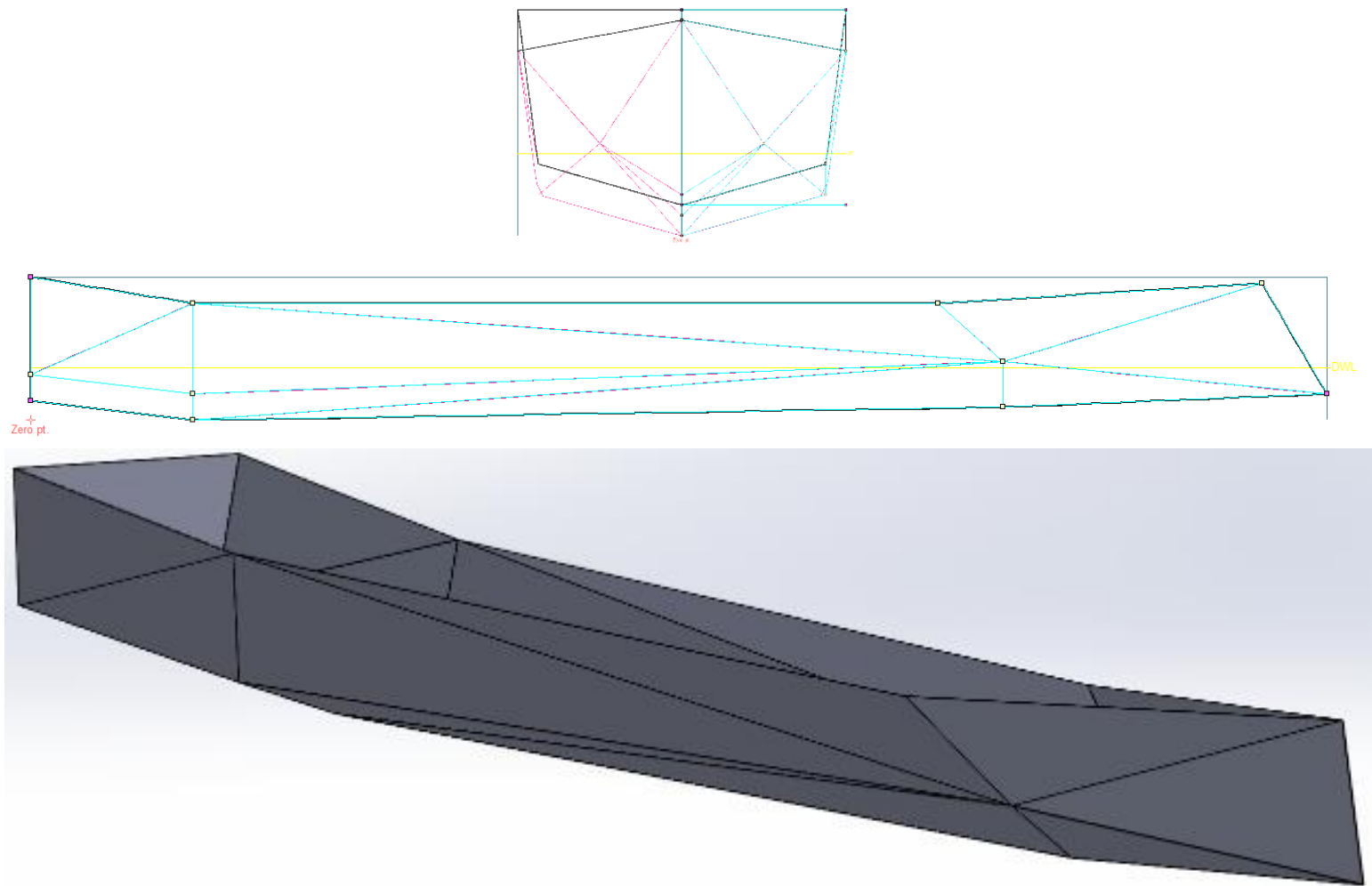

Figure 2 : Flat hull ship design for fishing tourism

\section{RESULTS AND DISCUSSION}

Ship stability analysis using Maxsurf Stability Software with two load case and a review of its compliance with the provisions of IMO A.749 (18) Chapter 3. is presented in table 2 for load case 1 (K1) and table 3 for load case 2 (K2).

Table 3 : Stability Analysis Results at Load case 1 (K1)

\begin{tabular}{rrrrrr}
\hline Criteria & Value & Units & Actual & Comment & Margin \% \\
\hline
\end{tabular}




\begin{tabular}{llllll}
\hline 3.1.2.1: Area 0 to 30 & 0.0550 & $\mathrm{~m} . \mathrm{rad}$ & 0.0644 & Pass & +17.08 \\
3.1.2.1: Area 0 to 40 & 0.0900 & $\mathrm{~m} . \mathrm{rad}$ & 0.1050 & Pass & +16.69 \\
3.1.2.1: Area 30 to 40 & 0.0300 & $\mathrm{~m} . \mathrm{rad}$ & 0.0406 & Pass & +35.42 \\
3.1.2.2: Max GZ at 30 or greater & 0.200 & $\mathrm{~m}$ & 0.373 & Pass & +86.50 \\
3.1.2.3: Angle of maximum GZ & $25^{0}$ & $\mathrm{deg}$ & 61.8 & Pass & +147.27 \\
3.1.2.4: Initial GMt & 0.150 & $\mathrm{~m}$ & 0.607 & Pass & +304.67 \\
\hline
\end{tabular}

Based on the results of the stability testing that has been carried out at load conditions 1 (K1, see table 3 ) the area of the GZ curve at an angle of $0^{\circ}-30^{\circ}$ is 0.0644 meter-radians, at an angle of $0^{0}-40^{\circ} \mathrm{GZ}$ area is 0.1050 meter-radians, at an angle of 300 - $400 \mathrm{GZ}$ area 0.0406 meter-radians, GZ value of $30^{\circ}$ angle is 0.373 meters, the maximum GZ angle is $61.8^{0}$ and GM value is 0.607 meters. The stability curve of a flat hull ship for fishing tourism under load case 1 is shown in Figure 3.

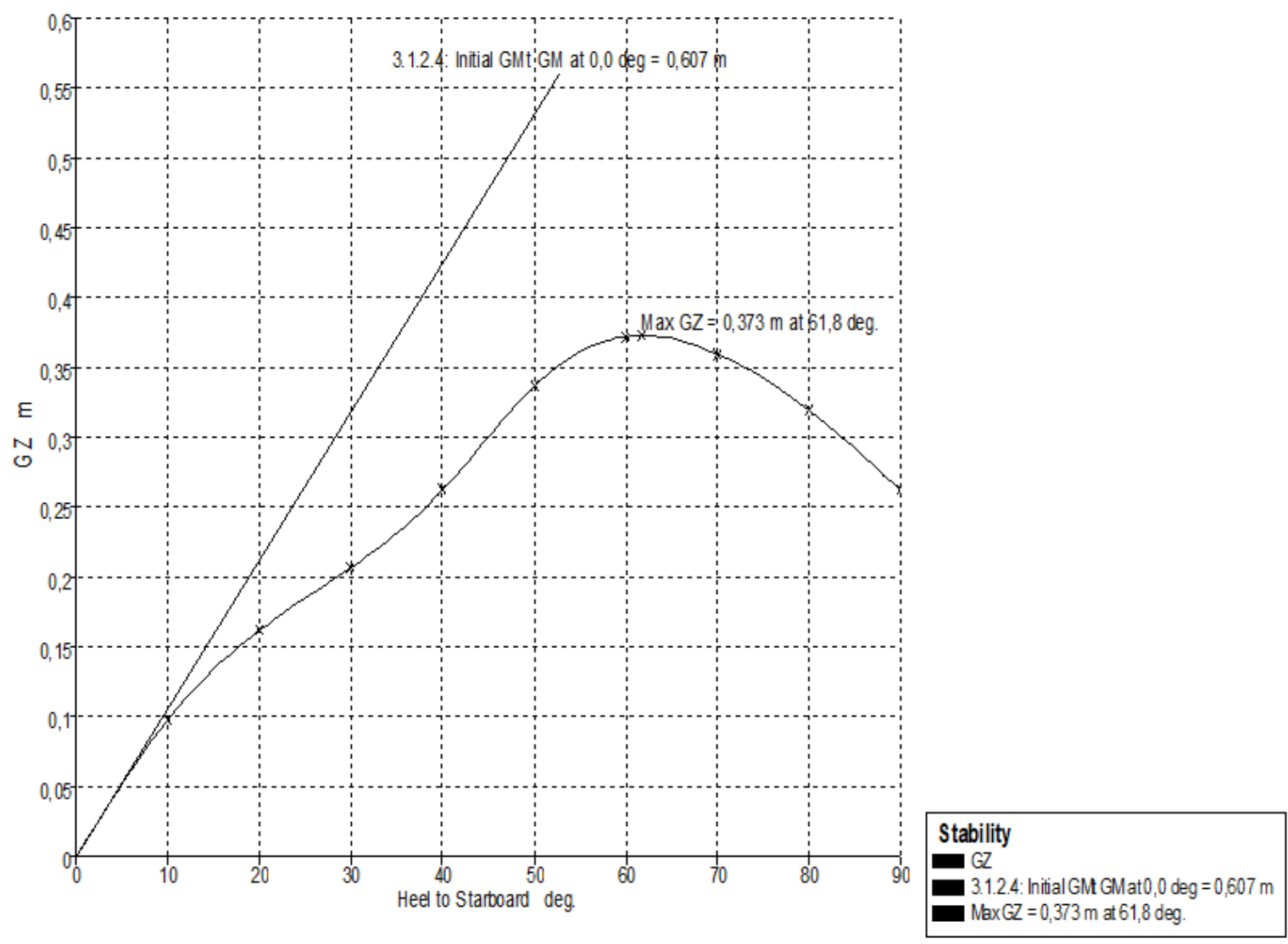

Figure 3 : Stability curve of a flat hull ship for fishing trips under load conditions 1 (K1)

Table 4 : Stability Analysis Results at Load case 1 (K2)

\begin{tabular}{llllll}
\hline \multicolumn{1}{c}{ Criteria } & \multicolumn{1}{c}{ Value } & \multicolumn{1}{c}{ Units } & \multicolumn{1}{c}{ Actual } & Comment & Margin \% \\
\hline 3.1.2.1: Area 0 to 30 & 0.0550 & m.rad & 0.0553 & Pass & +0.53 \\
3.1.2.1: Area 0 to 40 & 0.0900 & m.rad & 0.0924 & Pass & +2.72 \\
3.1.2.1: Area 30 to 40 & 0.0300 & m.rad & 0.0372 & Pass & +23.84 \\
3.1.2.2: Max GZ at 30 or greater & 0.200 & $\mathrm{~m}$ & 0.306 & Pass & +53.00 \\
3.1.2.3: Angle of maximum GZ & 25.0 & $\mathrm{deg}$ & 60.9 & Pass & +143.64 \\
3.1.2.4: Initial GMt & 0.150 & $\mathrm{~m}$ & 0.485 & Pass & +223.33 \\
\hline
\end{tabular}

In load case $2(\mathrm{~K} 2$, see table 4$)$ the area of the GZ curve at an angle of $0^{0}-30^{0}$ is 0.0553 meter-radians, at an angle of $0^{\circ}-40^{\circ}$ the area of GZ is 0.0924 meter-radians, at an angle of $30^{\circ}-40^{\circ}$ the area of GZ is 0.0372 meters -radian, the GZ value for the angle of $30^{\circ}$ is 0.306 meters, the angle at the maximum GZ is 
$60.9^{0}$ and the GM value is 0.485 meters. The stability curve of a flat hull ship for fishing tourism under load case 2 is shown in Figure 4.

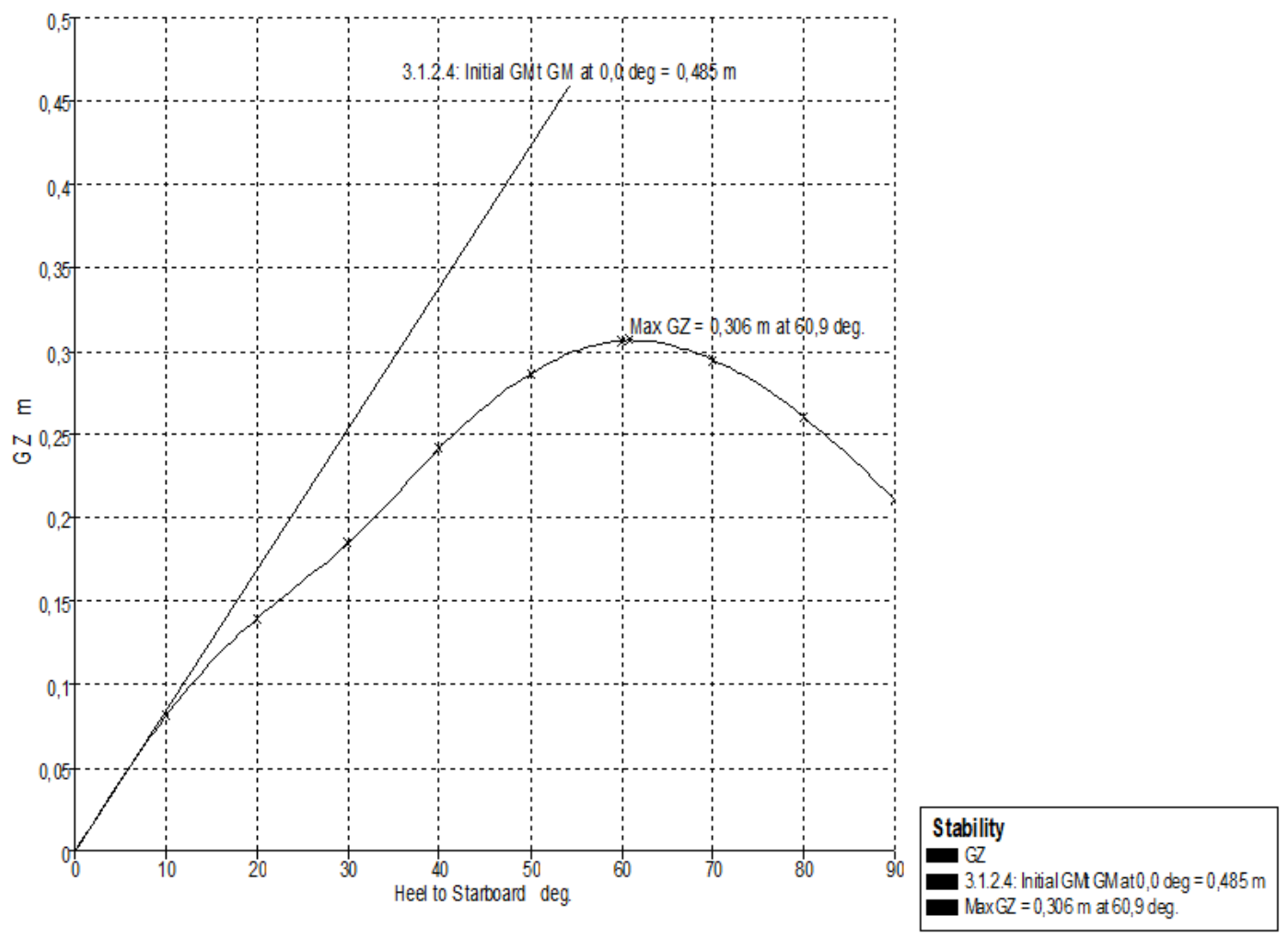

Figure 4 : The Stablity Curve

Based on the results of stability testing on the flat hull ship design for fishing tourism that has been carried out, the GZ values at $\mathrm{A} \mathrm{h} 30^{\circ}, \mathrm{A} \mathrm{h} 40^{\circ}$ and $\mathrm{A} \mathrm{h} 30^{\circ}-\mathrm{A} \mathrm{h} 40^{\circ}$ for loading conditions 1 and 2 are greater than the minimum standards determined by IMO. This indicates that the upholding moment or the moment that will return the ship to its original direction after experiencing a tilt due to external forces is bigger than predetermined conditions. From the tests that have been carried out, the maximum GZ value at load case 1 occurs at an angle of $61.8^{0}$ and at load condition 2 occurs at an angle of $60.9^{\circ}$. According to the IMO standard, the maximum GZ value must occur above an angle of $25^{\circ}$ [7]. This means that in load case 1 ship will return perpendicular to the original direction with a maximum angle of $61.8^{0}$ and for load case 2 ships will return perpendicular to the original direction with a maximum angle of $60.9^{0}$. The GM value at load case 1 is 0.607 meters and at load condition 2 is 0.485 meters. The GM value in both load case exceeds the IMO standard, it can be concluded that it meets the predetermined conditions.

\section{CONCLUSION}

Stability testing on a ship design is very important to do so that it can be seen whether the design meets the predetermined criteria and falls into the safe category when sailing. Testing the stability of the ship design using computer simulations can save testing time and cost. Based on the stability testing that has been carried out on the flat hull ship design for fishing tourism, it meets the criteria set by IMO. For further research, it is necessary to test the stability of this ship experimentally, to strengthen the validity of the test results, so that the ship design can be continued in the production stage. This ship model is suggested to be an alternative design for fishing tourism.

\section{ACKNOWLEDGEMENTS}

Authors thank Universitas Negeri Padang for the research support, due to the ethics committee permit number 353/UN35/KP/2019, the project number of this study was 793/UN35.13/LT/2019 and the budget of this study was Rp. 17.000.000. 


\section{REFERENCES}

[1] M. A. Rajab, A. Fahruddin, and I. Setyobudiandi, "Daya dukung perairan Pulau Liukang Loe untuk aktivitas ekowisata bahari," Depik J. Ilmu-Ilmu Perairan, Pesisir dan Perikan., vol. 2, no. 3, pp. 114 125, 2013.

[2] V. N. Bich, N. T. N. Hoa, and N. N. Tuan, "Perspective of Environment-Friendly Materials in Small Boats Manufactured in Vietnam," Int. J. Mech. Eng. Appl., vol. 3, no. 1, pp. 29-33, 2015.

[3] H. Tresno and M. A. Talahatu, "Pengembangan Desain Kapal Lambung Pelat Datar," in Seminar Nasional Tahunan Teknik Mesin (SNTTM) ke-9, 2010, pp. 135-138.

[4] Syahril and R. A. Nabawi, "Numerical investigation of the effect on four bow designs flat hull ship," Int. J. GEOMATE, vol. 17, no. 62, pp. 231-236, 2019.

[5] N. Afriansyah, B. A. Adietya, and G. Rindo, "Studi Desain Analisa Perbandingan Performance Kapal Perintis 750 DWT dengan Variasi Hull Menggunakan Pelat Datar,” J. Tek. Perkapalan, vol. 6, no. 1, pp. 160-167, 2018.

[6] G. L. Putra, H. T. Wibowo, and F. Agusta, "Stability analysis of semi-trimaran flat hull ship for a sea transportation model," Commun. Sci. Technol., vol. 2, no. 2, pp. 42-46, Dec. 2017.

[7] IMO, Adoption of the International Code on Intact Stability, vol. MSC.267, no. (85). London: IMO Publishing, 2008. 